Reprod. Nutr. Dévelop., 1981, 21 (4), 519-529.

\title{
Adaptation of hepatic enzyme activities to methionine excess
}

\author{
par D. FAU, Brigitte BOIS-JOYEUX, M. CHANEZ, Brigitte DELHOMME, J. PERET \\ Centre de Recherches sur la Nutrition du CNRS \\ 92190 Meudon Bellevue, France.
}

\begin{abstract}
Summary. Two groups of adult male rats 8 weeks old were fed a 10 p. 100 protein (casein) diet with or without 2 p. 100 methionine. After 8 rats in each group were killed at 10 a.m. on experimental days 1, 2, 4, 8 and 21, we studied the profiles of plasma non-esterified fatty acids (NEFA) and of the hepatic activities of pyruvate kinase (PK), phosphoenolpyruvate carboxykinase (PEPCK), glucose-6-phosphate dehydrogenase (G6PDH), malic enzyme (ME), acetyl-CoA-carboxylase (Ac. CoA carbox), alanine aminotransferase (AAT), 3-phosphoglycerate dehydrogenase (3PGDH), serine dehydratase (Ser DH), ATP-methionine adenosyltransferase (MAd T), cystathionine synthase (Cysta S) and cystathionase (Cysta $t)$.

Animal food intake and body weight dropped on the first two days of methionine excess ; from day 8 , they reached a new equilibrium which was much lower than that of the control animals.

Hepatic enzyme adaptation could be the result of two mechanisms : (i) a short-term, mainly catabolic, process on the first 4 days of excess during which phosphoenolpyruvate carboxykinase activity and the plasma NEFA level were high, while glucose-6-phosphate dehydrogenase and malic enzyme activities were declining; (ii) a later phenomenon, occurring on experimental day 8 and during which the activity of pyruvate kinase decreased slightly and that of malic enzyme and of 3-phosphoglycerate dehydrogenase declined sharply, while alanine aminotransferase activity was enhanced. The transsulfuration pathway specifically responded to methionine excess : ATP-methionine adenosyltransferase induction was immediate and depended on the amount of methionine ingested while cystathionine synthase did not seem to be closely regulated by methionine intake and cystathionase was only induced after 4 days. Each induction or repression has been discussed and related to the overall metabolic effects of the methionine excess reported in our previous papers.
\end{abstract}

\section{Introduction.}

Methionine has often been used for supplementation since it is found in deficient amounts in some vegetable proteins. Excessive methionine intake has been reported to have some pathological effects (Stekol and Szaran, 1962). Nevertheless, the essentiality of methionine and its efficiency as a growth promoter are still the subjects of a great number of studies in species as different as chicks (Katz and Baker, 1975), cats (Teeter ef al., 1978 ; Rogers and Morris, 1979), rabbits (Colin, 1978) and sheep (in relation to wool synthesis) (Radcliffe and Egan, 1978). Methionine fortification of soybean protein for the use of human infants and adults remains a problem today (Zezulka and Callo- 
way, 1976 ; Graham et al:, 1976 ; Fomon ef al., 1979), and some of its pharmacological effects are now being studied (Lim et al., 1979 ; Hladovec, 1980). We have already reported the metabolic implications of methionine excess (Fau et al., 1979 ; Fau and Peret, 1980) using either adapted rats (Fau ef al., 1980b) or pigs (Fau et al., 1980a), but it is imperative to know the successive steps of hepatic enzyme adaptation in order to understand how and when the rat can metabolize large amounts of diefary methionine.

\section{Material and methods.}

Animals. - The experiment was carried out using 88 young adult male Wistar CF rats 8 weeks old and weighing between 170 and $180 \mathrm{~g}$. They were housed in individual cages and maintained under controlled temperature $(22 \pm 2 \circ \mathrm{C})$ and lighting (light from 7 a.m. to 7 p.m.) conditions.

Diets. - The diets fed ad libitum had the following compositions $(\mathrm{g} / 100 \mathrm{~g}$ of diet) : casein (80 p. 100 protein) 12.5 (10.0 protein) with (or without) DL-methionine 2.0, sucrose 10.0, groundnut oil 8.0, salt mix 4.0 (Hubbel et al., 1937), vitamin mix 1.0 (Peret et al., 1973), powdered cellulose 2.0 , starch to complete $100 \mathrm{~g}$. The $10 \mathrm{p} .100$ casein diet contained 0.30 p. 100 of methionine in the protein and the imbalanced diet had 2.30 p. 100 of total methionine.

Experimental procedure. - The rats were fed a diet containing 10 p. 100 casein . protein for 10 days. They were then weighed and divided into 11 groups of 8 animals each. The first group was killed at the beginning of the experiment (day 0 ). The other 10 received either the control diet (10 p. 100 casein protein) or the experimental diet (10 p. 100 casein +2 p. 100 methionine). Animal body weight and food intake were recorded every 2 days at the beginning of the experiment and then every 3 days.

After 1, 2, 4, 8 and 21 days, 8 control and 8 experimental rats were killed by decapitation between 10 and $11 \mathrm{a} . \mathrm{m}$. Two blood samples were collected, the first one on 6 p. 100 PCA for ketone body determination, and the second one on heparin for NEFA determination. The liver was quickly removed, weighed and stored at $-80^{\circ} \mathrm{C}$.

Enzyme assay. - Phosphoenolpyruvate carboxykinase (PEPCK) (EC.4.1.1.32) and acetyl-CoA-carboxylase (Ac.CoA carbox) (EC.6.4.1.2) activities were measured by the methods of Chang and Lane (1966) and Chang ef al. (1967), respectively. The ${ }^{14} \mathrm{C}$ incorporated was measured using a Packard Tricarb liquid scintillation counter.

The activities of pyruvate kinase (PK) (EC.2.7.1.40), malic enzyme (ME) (EC.1.1.1.40) and glucose-6-phosphate dehydrogenase (G6PDH) (EC.1.1.1.49) were determined by the methods of Weber ef al. (1965), Hsu and Lardy (1969) and Fitch et al. (1959), respectively. For serine dehydratase (Ser DH) (EC.4.2.1.13) we used the method of Fallon et al. (1966) with the incubation medium of Suda and Nakagawa (1971). The activity of D-3-phosphoglycerate dehydrogenase (3PGDH) (EC.1.1.1.95) was measured using the method of Sallach (1966). NAD+ or NADPH release was measured at $37{ }^{\circ} \mathrm{C}$ and $340 \mu \mathrm{m}$ in a Gilford $300 \mathrm{~T}$ spectrophotometer.

The activity of ATP-methionine adenosyltransferase (MAdT) (EC. 2.5.1.6) was determined by using L-methionine (methyl- ${ }^{14} \mathrm{C}$ ) as a substrate (Mudd ef al., 1965). The 
S-adenosylmethionine formed was separated on cation exchange discs (P. 81) (McKenzie and Gholson, 1973) ; details of the method are given in a previous report (Fau ef al., 1979).

The activity of cystathionine synthase (Cysta S) (EC.4.2.1.22) was determined by the incubation medium of Mudd et al. (1965) with L-serine-U-14C. The labelled cystathionine formed was separated by paper chromatography using the descending technique fully described by Fau ef al. (1979).

The homoserine cleavage activity of cystathionase (Cysta t) (EC.4.4.1.1) was colorimetrically determined by the method of Greenberg (1962).

The livers were homogenized in sucrose or phosphate buffer (last 5 enzymes) (Fau ef al., 1979); all activities were measured in the $48000 \mathrm{~g}$ supernatant, and the protein content was determined by the Kjeldahl method $(N \times 6.25)$. The activities were expressed as nanomoles of substrate per minute per $\mathrm{mg}$ of protein at $37{ }^{\circ} \mathrm{C}$.

The concentrations of acetoacetate and $\beta$-hydroxybutyrate in the plasma were enzymatically measured according to Bergmeyer (1974). Plasma NEFA were extracted according to Dole and Meinertz (1960) and determined using the ${ }^{63} \mathrm{Ni}$ method of Ho (1970).

The results were statistically analyzed by variance analysis (Snedecor and Cochran, 1967) and the Newman-Keuls test.

\section{Results}

Figure 1 shows the typical effects of methionine excess on rat food intake and body weight. Food intake fell on day 1 of the experiment, followed by a reduction in body weight. The intake then rose progressively to $13 \mathrm{~g}$ within 4 days and never exceeded that value; at the same time, growth was restored and became linear after day 8 , but the weight gain of the excess methionine-fed animals was low $(1.3 \mathrm{~g})$ compared to that of the controls $(3.3 \mathrm{~g})$.
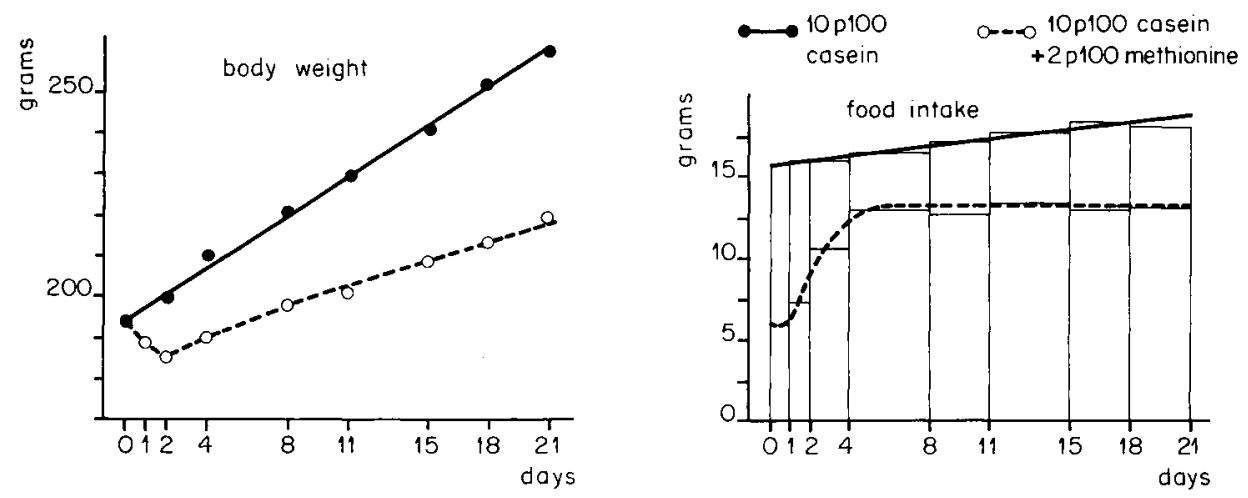

FIG. 1. - Food intake and body weight of rats fed excess methionine for 21 days.

(Food intake is expressed as grams per day of dry matter) (semi-synthetic diet, see methods). 
Some hepatic enzyme activity profiles are shown in figure 2. Excess methionine feeding was immediately followed by a strong rise in phosphoenolpyruvate carboxykinase activity (gluconeogenesis), which returned to normal after 21 days. On the other hand, pyruvate kinase activity, representative of glycolysis, was slightly reduced; this reduction only occurred after the second day but persisted. We studied three hepatic enzyme activities involved in lipogenesis; all of them were reduced by excess
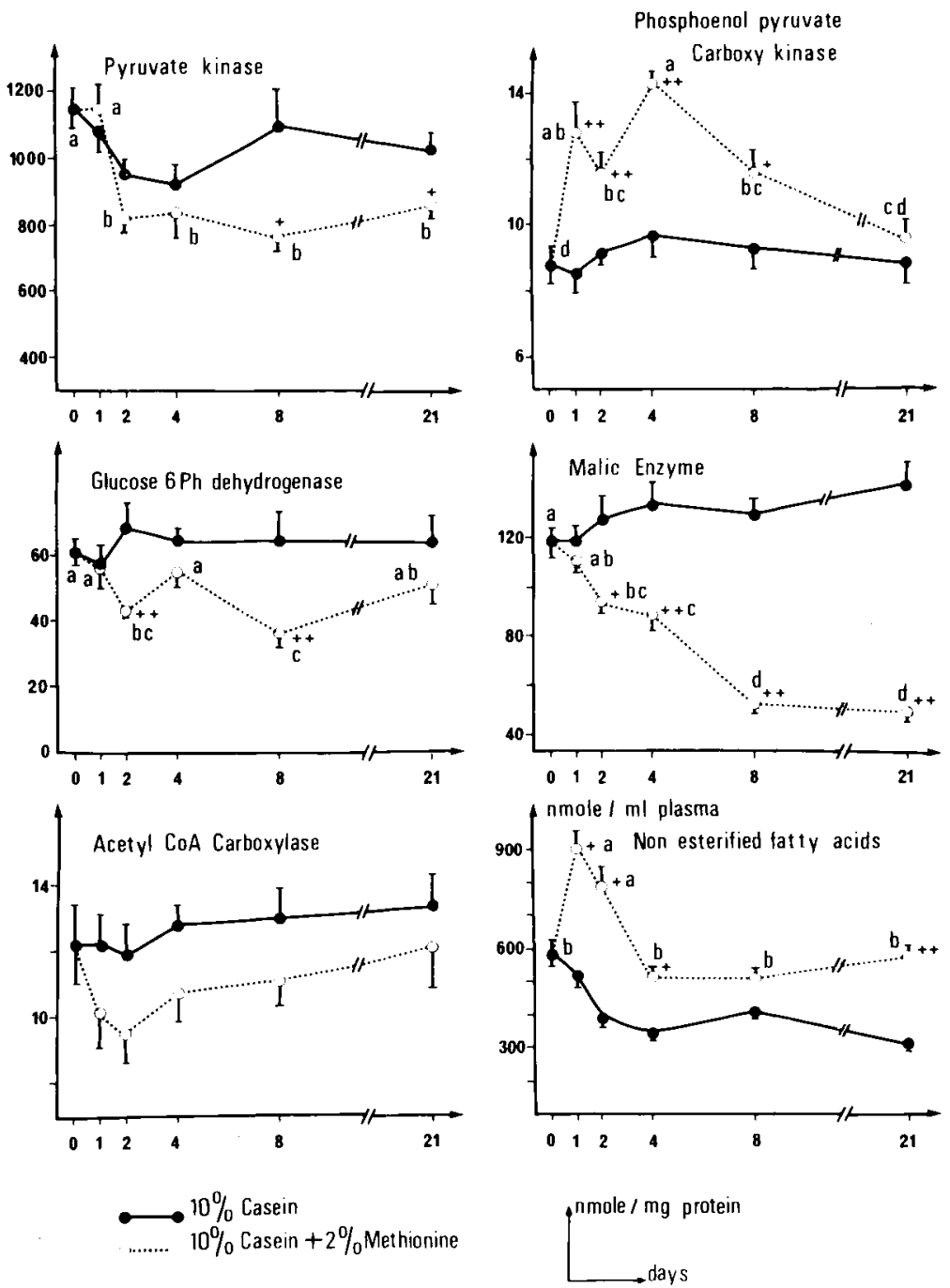

FIG. 2. - Hepatic enzyme activifies of rats fed methionine excess for 21 days. Enzyme activities are expressed in nanomoles of substrate converted per minute per $\mathrm{mg}$ proteins at $37^{\circ} \mathrm{C}$. Values for each group $(8$ rats) are the means \pm SEM. Statistical signification : In the methionine group : means not followed by the same letter are significantly different $(p<0.05)$; Between the experimental and the corresponding control group : $+: p<0.05 ;+\dashv-: p<0.01$. 

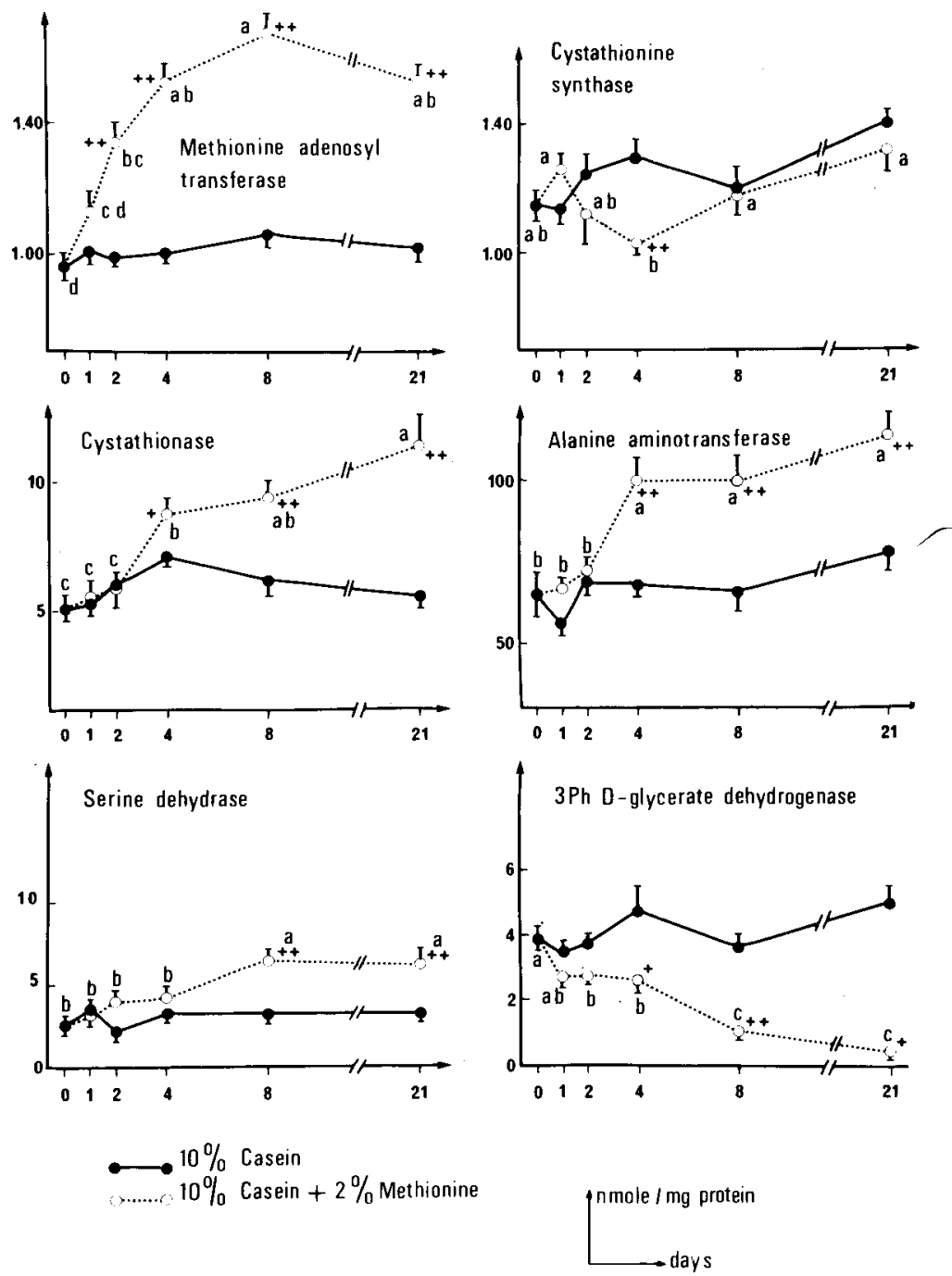

FIG. 2. - (continued).

methionine feeding : malic enzyme activity dropped on the second day of intake and, from day 8 until the end of the experiment, was about three times less that of the animals fed the control diet; between days 2 and 8 of methionine feeding, there was a slight reduction in glucose-6-phosphate dehydrogenase activity which returned close to normal after 3 weeks. The same observation was made for acetyl-CoA-carboxylase, but its activity was not significantly reduced because of high individual variability.

On the first two days of methionine intake, there was a high release of NEFA in the plasma, which made their concentration twice that of the normal animal. During the entire period, the NEFA remained slightly higher in the plasma of the methionine-fed 
animals. However, ketone body values were never high. The mean level of acetoacetate was slightly higher in the methionine-fed animals, but the difference was not significant (table 1).

TABLE 1

Plasma acetoacetate and hydroxybutyrate

\begin{tabular}{lcc}
\hline & $\begin{array}{c}\text { Control } \\
(48 \text { animals })\end{array}$ & $\begin{array}{c}\text { Methionine excess } \\
(40 \text { animals })\end{array}$ \\
\hline Acefoacetate...... & $54.4 \pm 4.4$ & $71.2 \pm 6.9$ \\
\hline B-OH-Butyrate $\ldots$ & $82.4 \pm 10.7$ & $87.6 \pm 13.8$ \\
\hline
\end{tabular}

Transamination intensity was represented by alanine aminotransferase (AAT) which doubled its activity on day 4 of methionine intake and then remained at that level. Serine dehydratase activity was slightly enhanced from day 8 to 21 , but the values ( $6 \mathrm{nmoles} / \mathrm{min} / \mathrm{mg}$ of protein) were in the same range as those reported in other experiments with animals fed a 10 p. 100 casein diet (Fau ef al., 1979). On the other hand, 3-phosphoglycerate dehydrogenase activity was reduced from day 4 , and was near zero after 3 weeks of methionine excess.

The transsulfuration pathway was represented by the activities of three enzymes: ATP-methionine adenosyltransferase (the first step) was enhanced from the first day of methionine intake and remained high throughout the experiment ; cystathionine synthase (the second step) was unchanged, except for a transitory reduction of its activity on day 4 of excess ; cystathionase was induced by methionine excess, but its activity only rose after 4 days and increased progressively up to the third week.

\section{Discussion.}

We used a low protein level (12.5 p. 100 casein, i.e. 10 p. 100 protein) to easily induce amino acid imbalance with 2 p. 100 of methionine, which was not toxic since the animals reached a new equilibrium in a few days, while maintaining continuous growth. As in previous studies (Fau ef al., 1980b), we used the racemic form of methionine (DLmethionine), commonly employed for supplementation (Kies ef al., 1975), assuming that not more than 94 p. 100 of either the DL-form, the protein methionine or the L-form was absorbed and utilized (Edwards ef al., 1963). Under our experimental conditions, animal food intake was not enhanced over $13 \mathrm{~g}$ per day, which corresponded to $260 \mathrm{mg}$ of free methionine ; we believe that this is the maximal amount of excess methionine that an adult rat, fed a 10 p. 100 casein diet, can metabolize. In a previous experiment (Fau et al., 1980b), the lower body weight gain of such rats was due, not only to lower protein deposition proportional to reduced food intake, but also to specific body lipid loss. 
Twenty-four hours after intake, methionine excess induces a corticosterone release (Munro et al., 1963) which itself is involved in the induction of phosphoenolpyruvate carboxykinase (gluconeogenesis), probably due to glucagon (Shrago et al., 1963 ; Kenney, 1970). This process could explain the time-limited induction of this enzyme (1 to 8 days), but there is no data in the literature concerning the glucagonemia of methionine-fed animals. On the other hand, the slight reduction in pyruvate kinase activity followed, by a delay, the reduction of food intake, and in this study, the induction or repression of pyruvate kinase and phosphoenolpyruvate carboxykinase were independent processes.

The effects of methionine excess on lipid metabolism are difficult to explain, partly because of the high individual variations in the activities of the pathway. The aggregate effect seems to be lower lipogenesis and enhanced lipolysis. As reported in our previous papers, malic enzyme activity was strongly depressed, but not sufficiently to conclude that lipogenesis was reduced since Stark ef al. (1975) challenged the concept that malic enzyme functions to provide NADPH for lipid synthesis.

Madvig and Abraham (1980) suggested that malic enzyme might play a role in supplying NADPH for the reduction of glutathione. An accumulation of reduced glutathione after methionine excess could repress malic enzyme synthesis (more data on this problem will be given in another paper). Madvig and Abraham (1980) also showed that 81 p. 100 of the NADPH generated in the pentose phosphate cycle was utilized for fatty acid synthesis. The simultaneous reduction of glucose-6-phosphate dehydrogenase and acetyl-CoA-carboxylase activities can then be considered as representative of a reduction in fatty acid synthesis, at least from experimental days 2 to 8 . This view, concerning the representativeness of lipogenic enzymes in relation to fatty acid synthesis, is in agreement with that of Nace and Szepesi (1976), Lent ef al. (1978) and Maeda ef al. (1975). Excess methionine intake is immediately followed by a high plasma NEFA level, probably due to the reduction of food intake. Nevertheless, it may be that these fatty acids are easily used for energy production, since we did not find any accumulation of ketone bodies in the plasma. After 21 days, when glucose-6-phosphate dehydrogenase and acetyl-CoA-carboxylase activities returned to normal, the plasma NEFA remained high. Since the body lipid of methionine-fed animals was very reduced (Fau et al., 1980), we could suppose that lipid furnover was enhanced under our experimental conditions.

Transamination intensity (alanine aminotransferase) was high from experimental day 4 to week 3, but we showed (Fau et al., 1980a) that this induction did not persist after 40 days of methionine intake. The higher activity could be a result of a transifory elevation of protein catabolism (Munro ef al., 1963), also responsible for a slight increase in serine dehydratase activity. Daniel and Waisman (1969) and Yokota ef al. (1977), who found activities ten or twenty times higher than ours for normal rats, reported that serine dehydratase induction occurred after methionine excess ; this was not the case in our experiment. Furthermore, Sanchez and Swendseid (1969) and Ogura (1970) did not obtain conclusive results with 2 p. 100 methionine. This discrepancy may be explained in two ways. Hara and Nakano (1979) considered that the inconsistency of the role of methionine in serine dehydratase induction was due to the strain of rats used : the Sprague-Dawley, but not the Wistar, rat strain showed significant induction. Hoshino ef al. (1971) reported that a large part of the serine dehydra- 
tase activity remaining after a long period of low-protein diet intake was not owing to «true » serine dehydratase but to homoserine dehydratase, in other words, to cystathionase, which is induced by methionine excess. We found a strong reduction in the activity of 3-phosphoglycerate dehydrogenase which synthesizes serine from glucose. This repression was reported to be simultaneous with transaminase induction in the case of high-protein diet (Suda, 1966 ; Fallon et al., 1966 ; Mauron ef al., 1973). In our experiment, the protein intake was low and feed-back control by serine concentration would hardly be credible. We believe that serine synthesis stopped since all the available glucose was used to cover the energy requirements enhanced by methionine excess (Fau et al., 1980b).

Transsulfuration is considered as the major pathway of methionine catabolism, although Mitchell and Benevenga (1978) stated that «transamination could be an alternative pathway for its oxidation $»$. However, these authors did not quantitatively estimate the proportion of methionine oxidized through transamination ( $\alpha$-keto- $\gamma-$ methiolbutyrate) and they do not mention sulfoxidation. ATP-methionine adenosyltransferase, the first step of transsulfuration, is induced by corticosteroids (Pan et al., 1968), and that is probably the case in our experiment which showed that ATP-methionine adenosyltransferase induction in vivo, under nutritional conditions, was proportional to methionine intake. Lombardini ef al. (1973) found a sigmoidal relation in vitro between ATP-methionine adenosyltransferase activity and methionine concentration. Our results are consistent with the views of Eloranta (1977) who considered that the rate-limiting factor of S-adenosylmethionine synthesis is tissue methionine concentration. He further suggested that glycine $\mathrm{N}$-methyltransferase may have a regulatory role in this pathway. We have no data concerning this enzyme which could increase a great deal under methioning excess. Our results, showing no change, or a slight reduction, in cystathionine synthase activity after methionine excess, agree with those in the literature (Daniel and Waisman, 1969). This enzyme represents the "cross-road» of sulfur metabolism (Finkelstein et al., 1974), but, as Stipanuk and Benevenga (1977), we believe that cystathionine synthase activity is not necessarily rate-limiting for methionine catabolism under our experimental conditions. The small, slow response of cystathionase to methionine induction, previously reported by Trautmann and Chatagner (1964), could be explained by the multiple functions of this enzyme (de Billy et al., 1975).

In conclusion, the response of hepatic enzyme activities to methionine excess can be divided into two periods. In the first (from experimental days 1 to 4), which is mainly catabolic, phosphoenolpyruvate carboxykinase activity (gluconeogenesis) increase sharply and NEFA are released into the plasma when food intake and body weight are depressed. During the second period (from day 8 to the end of the experiment), when the food intake is at a constant level and growth is linear, the hepatic enzyme activities gradually reach a new equilibrium as a result of adaptation mechanisms.

The occurrence of these two periods could be explained by the superposition of two types of metabolic response, one « phasic » and normal, consisting of some shortterm inductions, like that of phosphoenolpyruvate carboxykinase which has a half-life of about 5 or 6 hrs (Hopgood et al., 1973) (hormones such as glucagon and corticosterone are probably involved), and the other «tonic », as represented by the responses of pyruvate kinase, malic enzyme, alanine aminotransferase, 3-phosphoglycerate, dehydrogenase and cystathionase. The induction or repression of these enzymes is slows 
probably because of their long half-life ( $35 \mathrm{hrs}$ to 3 days for alanine aminotransferase ; Szepesi and Freedland, 1969), and persistent, presumably because their activities are regulated by substrate levels and/or flux.

Reçu en novembre 1980.

Accepté en février 1981.

Résumé. Deux groupes de rats mâles adultes, âgés de 8 semaines, sont nourris avec des régimes à 10 p. 100 de protéines (caséine), avec et sans 2 p. 100 de méthionine. Huit rats de chaque groupe sont tués à $10 \mathrm{~h}$ après $1,2,4,8$ et 21 jours de régime. On étudie l'évolution des acides gras non estérifiés (NEFA) plasmatiques, et des activités hépatiques de la pyruvate kinase (PK), la phosphoenolpyruvate carboxykinase (PEPCK), la glucose-6-phosphate déshydrogénase (G6PDH), l'enzyme malique (ME), l'acétyl-CoA-carboxylase (Ac.CoA carbox), l'alanine aminotransférase (AAT), la 3-phosphoglycérate déshydrogénase (3PGDH), I'ATP-méthionine adénosyltransférase (MAdT), la cystathionine synthase (Cysta S) et la cystathionase (Cysta t).

La consommation de nourriture et le poids corporel chutent brutalement les deux premiers jours d'ingestion d'un excès de méthionine ; à partir du 8 e jour, le gain de poids et les ingérés atteignent un nouvel équilibre, à un niveau inférieur à celui des animaux témoins.

L'adaptation des enzymes hépatiques peut être considérée comme le résultat de deux mécanismes :

- un phénomène à court terme dans lequel l'activité de la PEPCK et le niveau plasmatique des NEFA sont élevés, alors que les activités de la G6PDH et la ME s'abaissent ;

- un phénomène plus tardif pendant lequel la PK a une activité légèrement plus basse, celles de ME et 3 PGHD sont fortement réduites, alors que celle de l'AAT est élevée. La transsulfuration répond spécifiquement à l'excès de méthionine : l'induction de MAdT est immédiate et dépend de la quantité de méthionine ingérée, alors que la Cysta $S$ ne semble pas être régulée directement par l'ingestion de méthionine, et que la Cysta † n'est induite qu'après 4 jours d'excès. Chaque induction ou répression est discutée, pour elle-même ef par rapport aux effets métaboliques globaux de l'excès de méthionine, décrits dans nos articles précédents.

\section{References}

BERGMEYER H. U., 1974. Methods of enzymatic analysis. Acad. Press, New York, Vol. 4.

CHANG H. C., LANE M. D., 1966. The enzymatic carboxylation of phosphoenolpyruvate. J. biol. Chem., 241, 2413-2420.

CHANG H. C., SEIDMAN I., TEEBAR G., LANE M. D., 1967. Liver acefyl-CoA-carboxylase and fatty acid synthetase. Relative activities in the normal state and in hereditary obesity. Biochem. biophys. Res. Commun., 28, 682-686.

COLIN M., 1978. Effect of adding methionine to drinking water on growth of rabbits. Nutr. Rep. int., 17, 397-402.

DANIEL R. G., WAISMAN H. A., 1969. Adaptation of the weanling rat to diets containing excess methionine. J. Nutr., 99, 299-306.

de BILLY G., MULLER P., CHATAGNER F., 1975. New insights into the active center of rat liver cystathionase. Biochim. biophys. Acta, 397, 231-243.

DOLE V. P., MEINERTZ H., 1960. Microdetermination of long-chain fatty acids in plasma and tissues. J. biol. Chem., 235, 2595-2599.

EDWARDS C. H., GADSDEN E. L., EDWARDS G. A., 1963. Utilization of methionine by adult rat. II. - Absorption and tissue uptake of $L$ - and DL-methionine. J. Nutr., 80, 69-74.

ELORANTA T. O., 1977. Tissue distribution of S-adenosylmethionine and S-adenosylhomocysteine in rat. Effect of age, sex and methionine administration on the metabolism of S-adenosylmethionine, S-adenosylhomocysteine and polyamines. Biochem. J., 166, 521-529.

FALLON H. J., HACKNEY E. J., BYRNE W. L., 1966. Serine biosynthesis in rat liver. Regulation of enzyme concentration by dietary factors. J. biol. Chem., 241, 4157-4167. 
FAU D., CHANEZ M., BOIS-JOYEUX B., PERET J., 1979. Metabolic implications of methionine excess. Effects of methionine excess, dietary protein, fasting, cortisol and insulin on certain hepatic enzyme activities involved in transsulfuration, glycolysis, gluconeogenesis and lipogenesis in adapted adult rats. Ann. Biol. anim. Bioch. Biophys., 19, 343-353.

FAU D., DELHOMME B., BOURDON D., RÉRAT A., 1980a. Hepatic enzyme activities and muscle nucleic acid content in swine fed a diet imbalanced by methionine excess for hundred days. C. R. Acad. Sci. Paris, 291, 565-568.

FAU D., BOIS-JOYEUX B., DELHOMME B., CHANEZ M., PERET J., 1980b. Long-term effects of methionine excess on rat metabolism. Nutr. Rep. inf., 21, 577-585.

FAU D., PERET J., 1980. Methionine excess and energy requirement of the rat. Nufr. Rep. int., 22, $751-758$.

FINKELSTEIN J. D., KYLE W. E., HARRIS B. J., 1974. Methionine metabolism in mammals : regulatory effects of S-adenosylhomocysteine. Arch. Biochem. Biophys., 165, 774-779.

FITCH W. M., HILL R., CHAIKOFF I. L., 1959. The effect of fructose feeding on glycolytic enzyme activities of the normal rat liver. J. biol. Chem., 234, 1048-1051.

FOMON S. J., ZIEGLER E. E., FILER L. J., NELSON S. E., EDWARDS B. B., 1979. Methionine fortification of a soy protein formula fed to infants. Amer. J. clin. Nutr., 32, 2460-2471.

GRAHAM G. G., Mac LEAN W. C., PLAKO R. P., 1976. Plasma amino acids of infants consuming soybean proteins with and without added methionine. J. Nutr., 106, 1307-1313.

GREENBERG D.M., 1962. Cystathionine and homoserine cleavage. In COLOWICK S. P., KAPLAN N. O. Methods in enzymology, Vol. 5, 936-942, Acad. Press, New York.

HARA H., NAKANO K., 1979. Function of essential and non-essential amino acids in induction of some amino acid catabolizing enzymes in rat liver. Agric. biol. Chem., 43, 63-69.

HLADOVEC J., 1980. Methionine, pyridoxine and endothelial lesion in rats. Blood Vessels, 17, 104-109.

HO R. J., 1970. Radiochemical assay of long-chain fatty acids using ${ }^{63} \mathrm{Ni}$ as tracer. Analyt. Biochem., 36, 105-113.

HOPGOOD M. F., BALLARD F. J., RESHEF L., HANSON R. W., 1973. Synthesis and degradation of phosphoenolpyruvate carboxylase in rat liver adipose tissue. Biochem. J., 134, 445-453.

HOSHINO J., SIMON D., KRÖGER H., 1971. Identification of one of the L-serine dehydratase isoenzymes from rat liver as L-homoserine dehydratase. Biochem. biophys. Res. Commun., 44, 872-878.

HSU R. Y., LARDY H. A., 1969. Malic enzyme. In LOWENSTEIN J. M., Methods in enzymology, 17, 230-235, Acad. Press, New York.

HUBBEL R. B., MENDEL I. B., WAKEMAN A. J., 1937. A new salt mixture for use in experimental diets. J. Nutr., 14, 273-275.

KATZ R. S., BAKER D. H., 1975. Efficacy of D, L- and DL-methionine for growth of chicks fed crystalline amino acid diets. Poultry Sci., 54, 1667-1674.

KENNEY F. T., 1970. Hormonal regulation of synthesis of liver enzymes. In MUNRO H. N., Mammalian protein metabolism, 4, 131-176. Acad. Press, New York, London.

KIES C., FOX H., APRAHAMIAN S., 1975. Comparative value of L, DL- and D-methionine supplementation of an oat-based diet for humans. J. Nutr., 105, 809-814.

LENT B. A., LEE K. H., KIM K. H., 1978. Regulation of rat liver acetyl-CoA-carboxylase. J. biol. Chem., 252, 8149-8156.

LIM J. K., NARANG P. K., OVERMAN D. O., JACKNOWITZ A. I., 1979. Benefical effects of methionine and histidine in aspirin solutions on gastric mucosal damage in rats. J. pharm. Sci., 68, 295-298.

LOMBARDINI J. B., CHOU T. C., TALALAY P., 1973. Regulatory properties of adenosine triphosphate-L-methionine S-adenosyl transferase of rat liver. Biochem. J., 135, 43-47.

MCKENZIE R. M., GHOLSON R. K., 1973. A simple assay for methionine adenosyl-transferase using cation exchange paper and liquid scintillation spectrometry. Analyt. Biochem., 53, 384-391.

MADVIG P., ABRAHAM S., 1980. Relationship of malic enzyme activity to fatty acid synthesis and the pathway of glucose catabolism developing rat liver. J. Nutr., 110, 90-99.

MAEDA H., IKEDA I., SUGANO M., 1975. Behavior of the liver key lipogenesis enzymes in rat fed threonine imbalanced diet. Nutr. Rep. int., 12, 61-66.

MAURON J., MOTTU F., SPOHR G., 1973. Reciprocal induction and repression of serine dehydratase and phosphoglycerate dehydrogenase by proteins and dietary essential amino acids in rat liver. Eur. J. Biochem., 32, 331-342.

MITCHELL A. D., BENEVENGA N. J., 1978. The role of transamination in methionine oxidation in the rat. J. Nutr., 108, 67-78.

MUDD H. S., FINKELSTEIN J. D., IRREVERRE F., LASTER I., 1965. Transsulfuration in mammals. Microassays and tissue distributions of the three enzymes of the pathway. J. biol. Chem., 240, 4382-4392. 
MUNRO H. N., STEELE M. H., HUTCHISON W. C., 1963. Blood corticosterone levels in the rat after administration of amino acids. Nature, 199, $1182-1183$.

NACE C. S., SZEPESI B., 1967. Dietary fatty acids and the control of glucose-6-phosphate dehydrogenase and malic enzyme in the starved refed rat. J. Nutr., 106, 285-291.

OGURA M., 1970. On the relationship between food composition and serine dehydratase activity in rat liver. Part Il. On the factor of enzyme induction by high protein diet. Agr. biol. Chem., 34, 585-589.

PAN F., CHANG G. G., LEE S. C., 1968. Induction of methionine adenosyltransferase in rat liver by corticosteroids. Proc. Soc. exp. Biol. Med., 128, 611-616.

PERET J., MACAIRE I., CHANEZ M., 1973. Schedule of protein ingestion nitrogen and energy utilization and circadian rhythm of hepatic glycogen, plasma corticosterone and insulin in rats. J. Nutr., 103, 866-874.

RADCLIFFE B. C., EGAN A. R., 1978. The effects of diet and of methionine loading on activity of enzymes in the transsulfuration pathway in sheep. Aust. J. biol. Sci., 31, 105-114.

ROGERS Q. R., MORRIS J. G., 1979. Essentiallity of amino acids for the growing kitten. J. Nutr., 109, 718-723.

SALLACH H. J., 1966. D-3-Phosphoglycerate dehydrogenase in COLOWICK S. P., KAPLAN N. O., Methods in enzymology, Vol. 9, 216-220, Acad. Press, New York.

SANCHEZ A., SWENDSEID M. E., 1969. Amino acids levels and enzyme activity in tissues of rats force-fed diets differing in methionine content. J. Nutr., 99, 145-151.

SHRAGO E., LARDY H. A., NORDLIE R. C., FOSTER D. O., 1963. Metabolic and hormonal confrol of phosphoenolpyruvate carboxykinase and malic enzyme in rat liver. J. biol. Chem., 238, 31883192.

SNEDECOR G. W., COCHRAN W. G., 1967. Statistical methods, 5th Ed., lowa State Univ. Press, Ames.

STARK M. J., THOMPSON B., FRENKEL R., 1975. Possible alternative functions of rat liver malic enzyme. Arch. Biochem. Biophys., 166, 174-180.

STEKOL J. A., SZARAN J., 1962. Pathological effects of excessive methionine in the diet of growing rats. J. Nutr., 77, 81-90.

STIPANUK M. H., BENEVENGA N. J., 1977. Effect of cystine on the metabolism of methionine in rats. J. Nutr., 107, 1455-1467.

SUDA M., 1966. View of the comparison of the regulation of enzymes in mammalian and microbial systems Adv. Enz. Regul., 5, 181-209.

SUDA M., NAKAGAWA H., 1971. Serine dehydratase (rat liver). In TABOR H., TABOR C. W., Methods in enzymology, 17 (part b) 346-351, Acad. Press, New York.

SZEPESI B., FREEDLAND R. A., 1969. A possible method of estimating hormone effects on enzyme synthesis. Arch. Biochem. Biophys., 133, 60-69.

TEETER R. G., BAKER D. H., CORBIN J. E., 1978. Methionine essentiality for the cat. J. anim. Sci., 46, 1287-1292.

TRAUTMANN O., CHATAGNER F., 1964. Adaptation métabolique de la cystathionase du foie de rat. Bull. Soc. Chim. biol., 46, 129-139.

WEBER G., STAMM N. B., FISCHER E. A., 1965. Insulin inducer of pyruvate kinase. Science, 149, 6567.

YOKOTA F., TAKAHASHI S., ESASHI T., SUZUE R., 1977. The effect of glycine on the enzyme activities in the liver of rats fed excess methionine diet. Nut. Rep. int., 15, 347-353.

ZEZULKA A. Y., CALLOWAY D. H., 1976. Nitrogen retention in men fed isolated soybean protein supplemented with L-methionine, D-methionine, N-acetyl-L-methionine, or inorganic sulfate. J. Nutr., 106, 1286-1291. 